Jurnal Litbang Vol. XI, No. 2 Desember 2015: 103-112

\title{
PEMETAAN POTENSI BIOGAS DAN PUPUK DARI KOTORAN SAPI UNTUK MENDUKUNG WISATA PAMELO \\ DI DESA BAGENG KECAMATAN GEMBONG KABUPATEN PATI
}

\section{POTENTIAL BIOGAS MAPING AND SOLID MANURE FROM COW WASTE TO SUPPORT THE PAMELO TOURIST IN BAGENG VILLAGE GEMBONG SUBDISTRICT PATI REGENCY}

\author{
Hermain Teguh Prayitno \\ Kantor Penelitian dan Pengembangan Kabupaten Pati \\ Email: hermainteguh70@gmail.com
}

Naskah Masuk: 25 September 2015 Naskah Revisi: 6 Oktober 2015 Naskah Diterima: 16 Oktober 2015

\begin{abstract}
Bageng village is a village which has pummelo plant and the highest number of cattle in Gembong Subdistrict. Therefore, this area known as the Pummelo Tourism Village. High number of cattle not followed by good handling of cow waste so that in some areas experience the environmental pollution. To reach the better pummelo tourism village, it necessary to improve the quality of the environment. One of the way is by mapping the potential of biogas from cow waste. This study aims to: 1) describe the condition of cattle in Bageng village; 2) mapping the potential of biogas and manure from cow waste for development of Pummelo. This research is exploratory. The primary data required includes cage density, number of cattle, the amount of pummelo and public information obtained from the questionnaire. Secondary data were obtained from village and subdistrict monograph. Data processing is also reinforced with satellite images of google earth, the google MAP data. The results showed that : 1) The number of cattle counted 508-720 head with 8.7 tons of cow wastelday; 2) The largest biogas potency contained in Rubiyah hamlet Bageng village. From this research are expected the use of cow waste as biogas to meet the energy needs of the communities as well as to meet the needs of Pummelo plant manure.
\end{abstract}

Keywords: biogas, pummelo, solid manure

\begin{abstract}
ABSTRAK
Desa Bageng merupakan desa yang memiliki tanaman jeruk pamelo dan jumlah ternak sapi tertinggi di Kecamatan Gembong. Oleh karenanya, daerah ini dikenal sebagai Desa Wisata Pamelo. Jumlah ternak sapi yang tinggi tidak diikuti dengan penanganan kotoran sapi yang baik sehingga di beberapa daerah mengalami pencemaran lingkungan. Untuk menuju Desa Wisata Pamelo yang lebih baik, diperlukan adanya peningkatan kualitas lingkungan. Salah satunya dengan cara pemetaan potensi biogas dari kotoran sapi. Penelitian ini bertujuan untuk: 1) menggambarkan kondisi ternak sapi Desa Bageng; 2) memetakan potensi biogas dan pupuk dari pemanfaatan kotoran sapi untuk perkembangan Jeruk Pamelo. Penelitian ini merupakan penelitian eksploratif. Data primer yang dibutuhkan meliputi kerapatan kandang, jumlah ternak, jumlah jeruk pamelo dan informasi masyarakat yang diperoleh dari kuesioner. Data sekunder diperoleh dari Monografi Desa dan Kecamatan. Pengolahan data juga diperkuat dengan foto citra satelit google earth, data google MAP. Hasil penelitian ini menunjukkan bahwa: 1) Jumlah ternak sapi terhitung 508 - 720 ekor dengan 8,7 ton kotoran sapi /hari; 2) Potensi biogas terbesar terdapat di Dukuh Rubiyah Desa Bageng. Dari penelitian ini diharapkan adanya pemanfaatan kotoran sapi sebagai biogas untuk mencukupi kebutuhan masyarakat akan energi sekaligus untuk memenuhi kebutuhan pupuk tanaman Jeruk Pamelo.
\end{abstract}

Kata kunci: biogas, jeruk pamelo, pupuk padat 


\section{PENDAHULUAN}

Biogas adalah proses perombakan bahan organik menjadi anorganik dengan cara anaerob yang kemudian menghasilkan biogas. Bahan sisa yang dinamakan slurry bisa digunakan sebagai pupuk tanaman yang memiliki kandungan alami sehingga berpengaruh terhadap tanaman jangka panjang dan perbaikan struktur tanah. Jeruk Pamelo (Citrus maxima Merr.) yang sering disebut sebagai jeruk bali madu, kini menjadi buah andalan masyarakat Desa Bageng Kecamatan Gembong Kabupaten Pati. Meski produksi jeruk pamelo belum mampu untuk kebutuhan ekspor, namun buah jeruk tanpa biji ini mulai merambah swalayan-swalayan di beberapa kota besar di Jawa. Jeruk Pamelo atau disebut jeruk bali sangat bermanfaat, sebagai antioksidan yang handal sebagai pemulih stamina karena memiliki kandungan vitamin $\mathrm{C}$ yang cukup tinggi.

Rencana Pemerintah Kabupaten Pati untuk menjadikan Desa Bageng menjadi Desa Wisata Pamelo telah mendapat dukungan masyarakat, kondisi ini terlihat di setiap pekarangan warga yang hampir semuanya memiliki tanaman Jeruk Pamelo. Rasa manis dari Jeruk Pamelo Bageng tidak terlepas dari kebiasaan masyarakat dalam melakukan pemupukan. Pupuk yang biasa digunakan berupa feses dan urine sapi. Hal ini dapat dilihat dari adanya ember-ember di dekat kandang yang berfungsi untuk menampung urine cair tersebut. Hampir semua rumah memiliki kandang ternak sapi dan pohon Jeruk Pamelo. Akan tetapi sering dijumpai juga bahwa kandang sapi tanpa pintu, artinya keluar masuknya sapi melalui pintu utama rumah, dikarenakan lahan rumah yang sangat sempit. Hal ini menjadikan sebagian besar wilayah di Desa Bageng terlihat kumuh.
Beberapa hal yang harus dilakukan untuk mewujudkan Desa Wisata Pamelo yang lebih baik, salah satunya adalah wilayah atau desa tersebut harus memiliki lingkungan yang sehat sehingga diperlukan adanya penataan desa, salah satunya dengan cara pemetaan potensi desa yang dalam hal ini adalah potensi biogas. Berdasarkan latar belakang itu, maka tujuan penelitian ini adalah untuk: 1) Menggambarkan kondisi ternak sapi di Desa Bageng; 2) Memetakan potensi biogas dan pupuk untuk perkembangan jeruk Pamelo di Desa Bageng Kecamatan Gembong.

\section{TINJAUAN PUSTAKA}

\section{Jeruk Pamelo (Citrus maxima Merr.)}

Jeruk Pamelo atau Jeruk Bali atau Jeruk Besar merupakan buah jeruk terbesar. Nama "Pamelo" disarankan oleh Kementerian Pertanian karena jeruk ini tidak ada kaitannya dengan Bali. Jeruk ini termasuk jenis yang mampu beradaptasi dengan baik pada daerah kering dan relatif tahan penyakit, terutama Citrus Virus Phloem Degeneration (CVPD) yang pernah menghancurkan pertanaman jeruk di Indonesia. Beberapa kultivar unggulan di Indonesia seperti daerah Nambangan, Srinyonya, Magetan, yang terakhir ditanam di Bageng (tanpa biji) Kabupaten Pati (Suharijanto, 2011). Perkembangan jeruk di Kabupaten Pati sebenarnya sudah lama ada, terutama di Desa Bageng dan Desa Plukaran. Akan tetapi semenjak pemerintah antusias untuk mengembangkannya, salah satunya dengan mendaftarkan paten jeruk lokal di Pusat Perlindungan Varietas Tanaman Kementerian Pertanian Republik Indonesia, bernomer sertifikat: 01/PVL/2008 maka resmi Jeruk Bageng dikenalkan dengan dua nama yaitu jenis Jeruk Pamelo Bageng Madu dan Jeruk Pamelo Bageng Taji. 


\section{Pupuk Organik}

Pupuk organik banyak diperoleh dari bahan-bahan organik yang telah mengalami dekomposisi oleh mikroorganisme pengurai. Salah satu bahan organik yang banyak ditemukan dan belum dimanfaatkan adalah limbah dari instalasi biogas. Hal ini sesuai dengan hasil penelitian Wahyudi dan Astuti (2011) yang menyatakan bahwa limbah biogas (slurry) ketika dicampur dengan dedak dan Effective Microorganism (EM4) dalam proses anaerob selama kurang lebih 30 hari, dapat digunakan sebagai pupuk organik cair sesuai dengan spesifikasi kompos sampah organik menurut SNI 19-70302004. Hal ini dikarenakan slurry yang berasal dari biogas mengandung berbagai mineral yang dibutuhkan oleh tumbuhan seperti Phospor (P), Magnesium (Mg), Kalsium (Ca), Kalium (K), Tembaga $(\mathrm{Cu})$ dan Seng $(\mathrm{Zn})$. Hasil penelitian ini juga menyebutkan bahwa slurry murni tanpa tambahan apapun memiliki kualitas pupuk organik yang sesuai menurut SNI 19-7030-2004.

Tanaman jeruk membutuhkan pupuk organik sebanyak 20 - 40 $\mathrm{kg} /$ tanaman/tahun, dan di berikan setiap enam bulan sekali (Fiana dkk, 2015). Sedangkan menurut Purnomosidhi dkk (2002), tanaman jeruk membutuhkan 20 $\mathrm{kg}$ pupuk kandang/tanaman/tahun.

\section{Biogas}

Pengembangan biogas perlu segera dilakukan mengingat besarnya manfaat yang dapat diperoleh dari instalasi biogas. Prayitno (2014) menyatakan bahwa strategi pemanfaatan kotoran sapi dengan biogas, salah satunya dapat dilakukan melalui integrasi horisontal, dengan cara memperluas kegiatan lini produk atau membangun di tempat lain dengan tujuan meningkatkan jenis produk dan jasa.
Komposisi bahan biogas yang terdiri dari $58 \%$ feses, $27 \%$ air dan $15 \%$ starter (cairan slurry), mampu menghasilkan biogas 0,56 liter/kg/hari, bahan pupuk cair berupa cairan slurry $370 \mathrm{gr} / \mathrm{kg}$ feses, dan bahan pupuk padat berupa ampas slurry basah $740 \mathrm{gr} / \mathrm{kg}$ feses, dengan waktu proses anaerob 38 hari (Prayitno, 2014).

\section{Pemetaan}

Pemetaan adalah pengelompokkan suatu kumpulan wilayah yang berkaitan dengan beberapa letak geografis wilayah yang meliputi dataran tinggi, pegunungan, sumber daya dan potensi penduduk yang berpengaruh terhadap sosial kultural yang memilki ciri khas khusus dalam penggunaan skala yang tepat (Soekidjo,1994).

\section{METODE PENELITIAN}

\section{Tipe Penelitian}

Pemetaan potensi biogas dan pupuk didasarkan oleh eksplorasi sumber daya bahan baku. Penelitian eksploratif merupakan studi penjajakan. Pengetahuan tentang teori masih sangat sedikit atau samar-samar, dan dari hasil observasi baru dapat dirumuskan lebih rinci (Salim, 2007). Penelitian dilakukan dua tahap, yaitu analisa data sekunder dan analisa data primer berupa kondisi faktual di lokasi penelitian dengan kuesioner.

\section{Ruang Lingkup}

Ruang dari penelitian ini adalah peternakan sapi dan tanaman Jeruk Pamelo di Kecamatan Gembong. Sedangkan lingkup penelitian tentang jumlah kotoran sapi dikaitkan dengan potensi biogas dan pupuk untuk mendukung Jeruk Pamelo di Desa Bageng. 


\section{Sumber Data}

Data sekunder diperoleh dari Pemerintah Desa, instansi terkait dan dari foto citra satelit google earth atau Google Map. Data primer diperoleh dari kuesioner terhadap responden (peternak sapi) dengan indikator kondisi ternak sapi, pakan sapi, tanaman yang dimiliki, energi yang digunakan, serta kecukupan dalam penggunaan pupuk.

\section{Lokasi Pengambilan Sampel}

Desa Bageng terdiri dari 7 (tujuh) dukuh yaitu Dukuh Joho, Randu, Bageng, Blimbing, Rubiah, Koripan dan Pondokan. Adapun lokasi pengambilan sampel dilakukan di beberapa dukuh di Desa Bageng, yaitu Dukuh Joho, Dukuh Randu, Dukuh Bageng dan Dukuh Rubiyah. Penentuan lokasi pengambilan sampel ini didasarkan pada informasi awal yang diperoleh saat melakukan survei di Desa Bageng mengenai jumlah ternak sapi yang dimiliki. Keempat dukuh tersebut merupakan dukuh-dukuh yang memiliki ternak sapi tertinggi di Desa Bageng.

\section{HASIL DAN PEMBAHASAN}

\section{Gambaran Umum Desa Bageng}

Luas wilayah Desa Bageng 645,04 ha dari 6.730 ha luas wilayah Kecamatan Gembong. Desa Bageng terdiri dari 11 RW dan 26 RT. Jumlah penduduk tahun 2013 sebanyak 3.648 jiwa dengan luas pekarangan 126,12 ha. Tegal seluas 355,15 ha tertanami tanaman utama ketela pohon 274 ha dan tanaman padi 9 ha. Peternakan sapi di Bageng juga memberikan data jumlah yang besar 702 ekor yaitu $20 \%$ dari total 3.506 ekor sapi di Kecamatan Gembong (BPS Kab. Pati, 2014).

Menurut data dari Balai Penyuluh Pertanian Kecamatan Gembong (2014), jumlah Jeruk Pamelo di Desa Bageng sebanyak 8.912 tanaman yaitu $45 \%$ sebesar 19.596 batang di seluruh Kecamatan Gembong. Data monografi Kecamatan Gembong disajikan pada Tabel 1.

Tabel 1.

Data Monografi Kecamatan Gembong 2014

\begin{tabular}{lcccccccc}
\hline \multirow{2}{*}{ Nama Desa } & $\begin{array}{c}\text { Luas } \\
\text { (Ha) }\end{array}$ & \multicolumn{2}{c}{ Penduduk } & \multicolumn{2}{c}{ Peternakan Sapi } & \multicolumn{3}{c}{ Tanaman Tegalan } \\
\cline { 3 - 9 } & $\mathbf{2 0 1 1}$ & $\mathbf{2 0 1 3}$ & Peternak & Sapi & Ketela & Padi & Jeruk Pamelo *) \\
\hline Bremi & 768,63 & 4300 & 4314 & 49 & 80 & 691 & 33 & 85 \\
Kedungbulus & 511,18 & 2313 & 2320 & 60 & 103 & 378 & 38 & 80 \\
Semirejo & 550,8 & 3779 & 3145 & 143 & 259 & 256 & 61 & \\
Wonosekar & 306,93 & 1520 & 1535 & 143 & 259 & 255 & 7 & \\
Gembong & 679,39 & 8932 & 9045 & 226 & 429 & 526 & 27 & 1505 \\
Plukaran & 616,28 & 2742 & 2748 & 180 & 273 & 244 & 53 & 2709 \\
Bageng & 645,04 & 3645 & 3648 & 350 & 702 & 274 & 9 & 8912 \\
Pohgading & 407,21 & 3099 & 3112 & 172 & 321 & 266 & 34 & 2668 \\
Klakahkasihan & 801,41 & 6971 & 7055 & 326 & 581 & 201 & 162 & 1077 \\
Ketanggan & 292,93 & 1603 & 1617 & 73 & 124 & 254 & 36 & 168 \\
Sitiluhur & 1150,2 & 3567 & 3570 & 229 & 375 & 257 & 80 & 2392 \\
\hline Sumber: BPS Kab & Pati & & &
\end{tabular}

Sumber: BPS Kab. Pati (2014), *) Balai Penyuluhan Pertanian Gembong (2014) 


\section{Peta Desa Bageng}

Desa Bageng belum memiliki peta administrasi desa yang memadai, hanya peta situasi desa yang dibuat oleh aparatur pemerintah desa. Untuk penelitian pemetaan potensi, sangatlah membutuhkan peta desa, maka pembuatan pendekatan peta administrasi desa penting dilakukan dengan mengkompilasi tiga sumber data yaitu Peta Situasi Desa Bageng, Peta lokasi Google Map, dan Foto citra satelit Google earth. Ketiga data dikompilasi dengan program Autocad dan hasilnya dapat dilihat pada Gambar 1.

Untuk mendapatkan data kompilasi peta seperti dalam gambar peta di atas, dapat dilakukan dengan cara mengukur panjang lokasi pertigaan Dukuh Rubiyah sampai perempatan Gembong-Bageng di citra satelit google earth. Dari hasil pengukuran itu diperoleh hasil 1.920,04 meter yang kemudian digunakan untuk mengukur peta lokasi desa di Google Map dalam program skala Autocad.

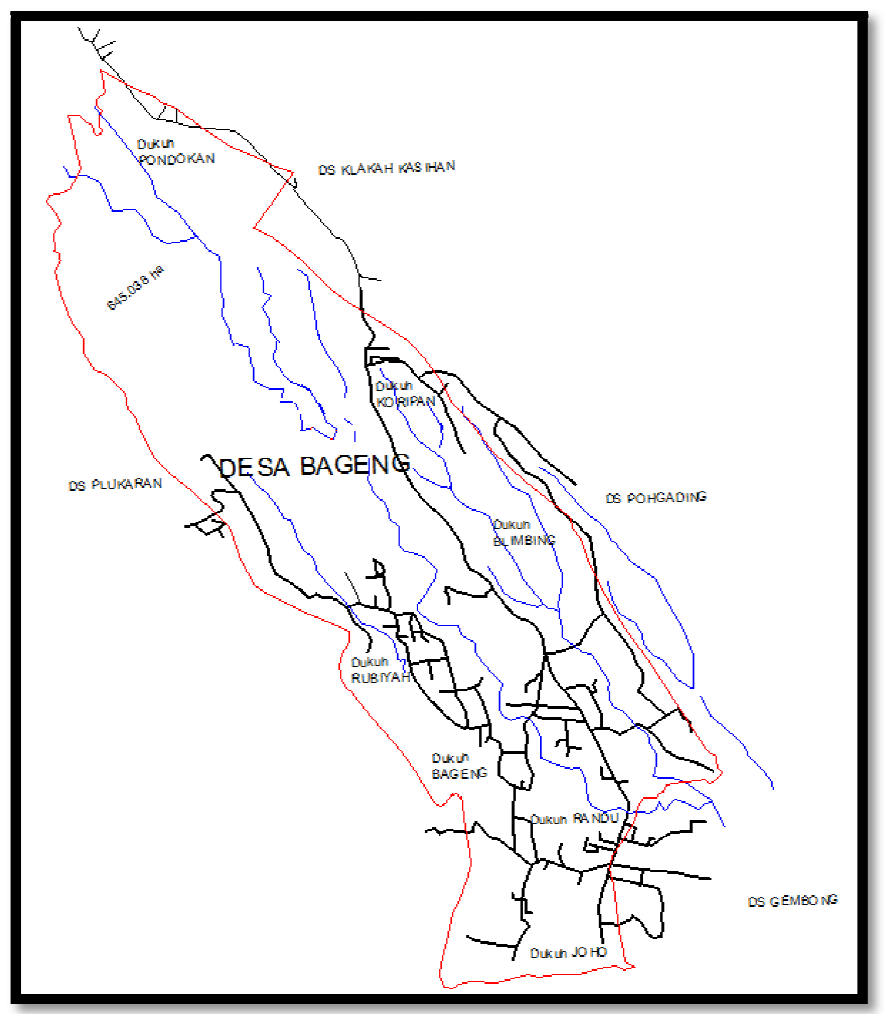

Gambar 1.

Peta Desa Bageng

Sumber: Pengolahan Data (2015)

\section{Kondisi Ternak Sapi di Desa Bageng}

Kondisi ternak sapi di Desa Bageng dapat diketahui dari jumlah kandang dan ternak, jenis pakan, kondisi pupuk tanaman, tanaman sekitar, serta pengetahuan tentang pemakaian gas.
Dari hasil wawancara terhadap 53 responden yang merupakan peternak sapi, Desa Bageng terbagi dalam 3 wilayah yaitu wilayah yang memiliki banyak ternak sapi (Dukuh Rubiyah), wilayah yang memiliki ternak sapi dengan jumlah sedang (Dukuh Bageng), 
dan wilayah yang memiliki ternak sapi sedikit (Dukuh Joho). Penggolongan wilayah ini sesuai dengan informasi awal yang diperoleh dari masyarakat.

Dari hasil wawancara dan kuesioner dapat diketahui bahwa pakan ternak sapi yang diberikan relatif sama, yaitu sebesar 80,77\% pakan merupakan daun tebu, dimana disaat penelitian ini diambil bersamaan dengan musim tebang tebu, sehingga banyak ternak sapi diberi pakan yang mudah dan murah didapatkan. Sebanyak 71,15\% pakan sapi yang diberikan merupakan rumput gajah, hal ini menggambarkan bahwa peternak memang sudah mempersiapkan tanaman rumput gajah untuk menjadikan makanan utama ternak sapi. Pakan ternak sapi yang sering diberikan berikutnya adalah daun ketela $(28,85 \%)$. Penggunaan daun ketela sebagai pakan ternak sapi seharusnya bisa lebih banyak, namun saat ini persentase penggunaannya masih berada dibawah persentase pakan daun tebu saat panen tebu seperti sekarang ini. Rumput juga digunakan ebagai pakan ternak sapi dengan persentase $26,92 \%$. Ampas ketela dan bekatul termasuk pakan yang memiliki nilai ekonomi, akan tetapi untuk berhemat maka pakan ini kurang diminati, hal ini terbukti dengan kecilnya persentase pemakaian pakan ini yaitu hanya pada $11,5 \%$ dan $3,8 \%$ saja.

Setiap peternak rata-rata memiliki tanaman Jeruk Pamelo 7 batang, dan sebagian besar lainnya adalah tanaman kopi, akan tetapi lokasi tanaman Jeruk Pamelo ini berada jauh dari rumah.

Untuk penggunaan energi memasak, sebanyak 94,2\% dari peternak di Desa Bageng sudah menggunakan LPG konversi pemerintah, dan juga masih menggunakan energi pendamping yaitu kayu bakar sebesar 90,38\%. Kotoran sapi umumnya belum dikelola dengan benar untuk dijadikan pupuk. Padahal kotoran sapi memiliki potensi besar untuk dimanfaatkan sebagi bahan baku energi terbarukan biogas.

Kotoran sapi yang dihasilkan dari ternak oleh para peternak tidak dikelola dengan baik. Sebanyak 76,8\% peternak melakukan penjemuran dan penimbunan kotoran sapi karena kurangnya lahan untuk pengolahan dan penyimpanan. Sebagian besar kotoran sapi masih dibuang melalui pengguyuran menuju ke sungai dan sebagian kecil dijual.

\section{Peta Kerapatan Ternak Sapi}

Untuk menentukan kerapatan jumlah ternak di Dukuh Joho, Dukuh Bageng dan Dukuh Rubiyah, dilakukan dengan cara membandingkan jarak antar responden di setiap RW dengan jumlah sapi yang dimiliki. Dari perhitungan ini diperoleh hasil bahwa RW 8 memiliki kerapatan jumlah ternak sapi Sangat Tinggi (15 meter setiap kandang), RW 7 Tinggi (20 meter), RW 3 Sedang (25 meter), dan RW 1 Kecil (60 meter). Banyaknya jumlah kandang di setiap dukuh ternyata didukung oleh faktor lingkungan, dimana lokasi RW 8 dan RW 7 berada di atas sungai. Maka kemungkinan untuk mendapatkan sumber air untuk mengelola peternakan sapi lebih mudah.

Setelah mengetahui kerapatan jarak antar responden masing masing dukuh dan informasi jumlah ternak yang dimiliki responden tersebut maka dapat digambarkan ke dalam bentuk peta sebagai yang ditampilkan pada Gambar 2.

Pada gambar 2 terdapat 2 (dua) garis arsir merah yang memiliki kerapatan berbeda. Hal ini menggambarkan bahwa garis arsir merah di sebelah kiri yaitu di lokasi RW 9 mempunyai kerapatan ternak Sangat Tinggi dan arsir warna merah di sebelah 
kanan merupakan lokasi di RW 8 dan RW 7 menggambarkan bahwa daerah tersebut mempunyai kerapatan ternak Tinggi. Sedangkan arsir warna kuning di RW 3, RW4, RW 5 dan RW 6 memiliki kerapatan ternak Sedang, dan arsir warna hijau di RW 1 dan RW 2 memiliki kerapatan ternak Kecil.
Garis kerapatan tersebut juga dapat digunakan untuk menggambarkan kondisi kesehatan lingkungan dimana garis warna merah memiliki lingkungan yang kotor, warna kuning memiliki lingkungan yang bersih, dan warna hijau menggambarkan lingkungan yang sehat dan bersih.

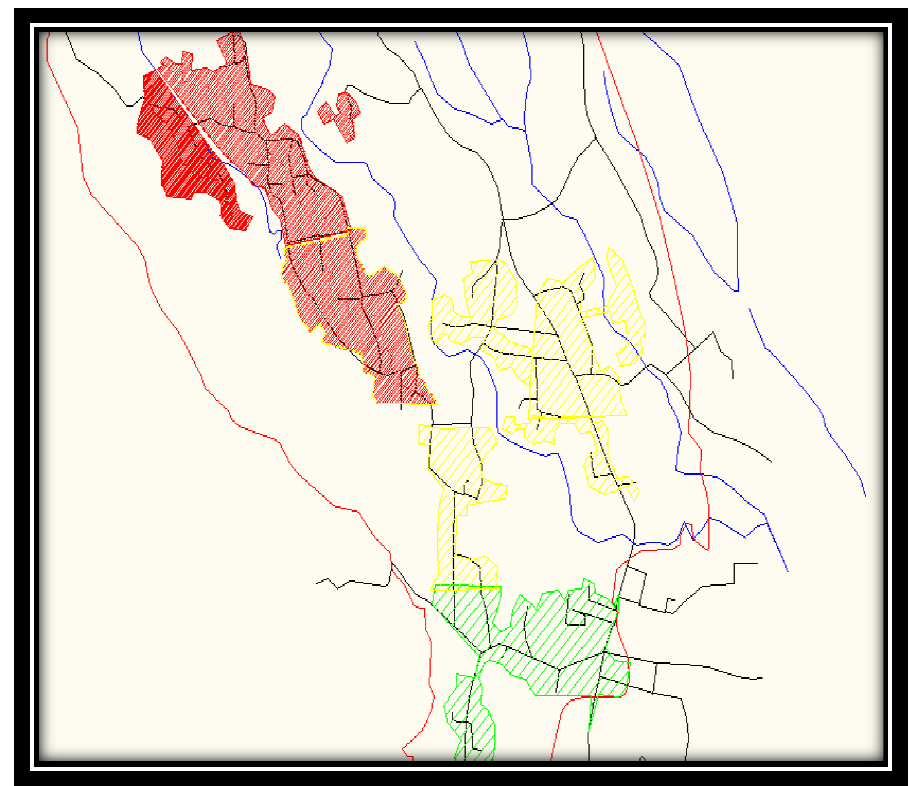

Gambar 2.

Peta Kerapatan Ternak di Desa Bageng

Sumber: Pengolahan Data (2015)

\section{Potensi Biogas}

Ukuran sapi merupakan salah satu hal yang dapat mempengaruhi potensi biogas. Hal ini berkaitan dengan jumlah kotoran yang dihasilkan setiap harinya. Menurut (Parhusip dan Ayunani, 2009) lingkar dada sapi $206 \mathrm{~cm}$ memiliki berat badan maksimum 450,1 kg, sedangkan hasil pengukuran sapi umur 3 tahun lebar dada sapi $203 \mathrm{~cm}$ dan panjang $128 \mathrm{~cm}$ mengeluarkan feses sekitar $15 \mathrm{~kg}$ setiap hari (Prayitno, 2015). Maka ukuran sapi dibedakan dalam tiga ukuran yaitu sapi besar menghasilkan kurang lebih $18 \mathrm{~kg}$ kotoran per hari, sapi sedang $12 \mathrm{~kg}$ kotoran per hari dan sapi kecil $6 \mathrm{~kg}$ kotoran per hari yang disajikan pada Tabel 2.

Tabel 2.

Perkiraan Potensi Biogas dan Pupuk Organik

\begin{tabular}{cccccccc}
\hline \multirow{2}{*}{$\begin{array}{c}\text { Ternak Sapi } \\
\text { (ekor) }\end{array}$} & \multicolumn{3}{c}{ Kotoran Sapi (kg/hari) } & \multirow{2}{*}{ Jumlah } & \multicolumn{2}{c}{ Potensi } \\
\cline { 2 - 4 } & Besar & Sedang & Kecil & & Biogas (m3/hari) & Pupuk (ton/hari) \\
\hline 508 & 2.334 & 3.177 & 681 & 6.193 & 131,78 & 4,58 \\
720 & 3.309 & 4.503 & 965 & 8.778 & 186,79 & 6,50 \\
\hline
\end{tabular}

Sumber: Pengolahan Data (2015), *) BPS Kab. Pati (2014). 
Tabel 2 menggambarkan perkiraan potensi biogas dan pupuk yang dihasilkan dari ternak sapi yang ada di Desa Bageng. Perhitungan perkiraan potensi biogas dimulai dengan menghitung jumlah ternak sapi sehingga jumlah kotoran sapi dapat diperkirakan setiap harinya. Dari 53 responden pada penelitian ini, ada 1 responden yang dikeluarkan karena memiliki ternak sapi yang banyak berbentuk usaha dagang dan penggemukan. Ternak sapi dari 52 responden ini berjumlah 94 ekor maka setiap kandang rata-rata berjumlah 1,8 ekor sapi. Informasi masyarakat yang diperoleh menyatakan bahwa jumlah kandang di Desa Bageng sebanyak 281 dikalikan dengan 1,8 ekor sapi maka diperoleh jumlah sapi sebanyak 508 ekor sapi. Data ini lebih kecil dari jumlah sapi yang diperoleh dari BPS Kab. Pati (2014) yaitu sebanyak 720 ekor sapi. Perbedaan jumlah ini dikarenakan waktu penelitian dilaksanakan saat musim kemarau dimana menurut informasi dari responden setiap kandang biasanya berisi 3 ekor sapi dan pada musim kemarau telah dijual tinggal 1 sampai 2 ekor sapi.

Perbandingan jumlah sapi berdasarkan ukuran tubuhnya dari 52 responden ditemukan bahwa Sapi Besar berjumlah 25,5\%; Sapi Sedang 52,1\% dan Sapi Kecil 22,3\%. Berdasarkan banyaknya jumlah kotoran yang dihasilkan dari masing-masing ukuran sapi, maka dapat diperkirakan bahwa dari 508 ekor sapi diperoleh kotoran sapi sebesar 6,193 ton/hari. Sedangkan jika sesuai dengan data dari KBPS Kab. Pati (2014) yang menyatakan bahwa jumlah sapi 720 ekor sapi diperoleh kotoran sapi sebesar 8,778 ton/hari.

Menurut Prayitno (2015), setiap 1 kg kotoran sapi menghasilkan 0,56 liter biogas setiap hari selama 38 hari, dan menghasilkan sisa padatan slurry basah $0,74 \mathrm{~kg}$. Maka berdasarkan hal tersebut, kotoran sapi di Desa Bageng seluruhnya akan menghasilkan paling sedikit 131,78 $\mathrm{m}^{3}$ setara dengan 22 tabung LPG $3 \mathrm{~kg}$ dan paling banyak musim penghujan menghasilkan $186,79 \mathrm{~m}^{3}$ setara 31 tabung.

\section{Potensi Pupuk}

Pada Tabel 2 juga dijelaskan perhitungan jumlah ampas slurry basah kondisi minimal 4,58 ton/hari dan kondisi maksimal saat musim penghujan sebesar 6,5 ton/hari. Jika slurry ini ditambah EM4 dan dedak kemudian dibiarkan kondisi anaerob selama 30 hari maka pupuk organik dapat diaplikasikan pada tanaman. Menurut Fiana dkk., (2015) untuk tanaman jeruk membutuhkan $6,6 \mathrm{~kg}$ pupuk organik setiap 2 bulan atau dapat disediakan $0,111 \mathrm{~kg}$ untuk setiap batang setiap hari. Maka prediksi pupuk yang tersedia di Desa Bageng setelah proses biogas dan pupuk, mampu memupuk paling sedikit 41.285 batang Jeruk Pamelo dan maksimal sebanyak 58.519 batang Jeruk Pamelo pada musim penghujan. Maka potensi pupuk ini diperkirakan mencukupi kebutuhan Jeruk Pamelo akan pupuk organik. Pupuk inipun juga dapat diaplikasikan untuk komoditas lain yang banyak terdapat di Desa Bageng, seperti Tanaman Kopi dan lainnya.

\section{KESIMPULAN DAN SARAN}

\section{Kesimpulan}

Berdasarkan pengamatan dan analisa hasil pemetaan potensi dapat ditarik beberapa kesimpulan bahwa:

1) Hampir semua rumah masyarakat di Desa Bageng memiliki tanaman jeruk pamelo dan ternak sapi. Masyarakat memanfaatkan kotoran sapi sebagai pupuk kandang untuk Jeruk Pamelo setelah melalui proses penjemuran terlebih dahulu. Total kotoran sapi yang dihasilkan di Desa Bageng diperkirakan antara $6.193 \mathrm{~kg} / \mathrm{hari}$ 
sampai dengan $8.778 \mathrm{~kg} / \mathrm{hari}$. Banyaknya kotoran sapi tersebut berpotensi untuk diolah menghasilkan biogas sebanyak $131,78 \mathrm{~m}^{3} /$ hari $186,79 \quad \mathrm{~m}^{3} /$ hari, $\quad$ sekaligus menghasilkan pupuk organik yang dapat mencukupi kebutuhan pupuk tanaman Jeruk Pamelo sebanyak 58.519 batang. Pengembangan biogas kotoran sapi ini mampu meningkatkan perekonomian masyarakat melalui penghematan pembelian LPG serta mampu menghasilkan pupuk organik untuk pertumbuhan Jeruk Pamelo.

2) Karakteristik lingkungan wilayah atas dengan wilayah bawah memiliki perbedaan terutama didekat sungai terlihat sangat kumuh dan berceceran kotoran sapi yang dialirkan tersumbat di selokan-selokan menuju sungai, dikarenakan tidak mempunyai lahan pengolahan, penyimpanan, dan alat transportasi memadahi. Berdasarkan analisa dan perhitungan jumlah peternak dan kerapatan ternak, wilayah atas yang berdekatan dengan sungai berpotensi dikembangkan biogas dan pupuk guna mendukung Wisata Pamelo dan meningkatkan kesehatan lingkungan.

\section{Saran}

- Mensosialisasikan manfaat biogas untuk penghematan energi dan produksi pupuk untuk meningkatkan pertumbuhan dan produksi Jeruk Pamelo di Desa Bageng.

- Membuat proyek percontohan pembangunan biogas dan pupuk skala kecil yang disesuaikan dengan jumlah ternak dan luas lahan yang dimiliki masyarakat sehingga biaya murah dan terjangkau pengadaannya.

- Mengembangkan Wisata Pamelo beserta Wisata Desa Mandiri Energi dan Pupuk untuk dapat terapkan di Desa Bageng.

\section{DAFTAR PUSTAKA}

Badan Pusat Statistik Kabupaten Pati. 2014. Kecamatan Gembong Dalam Angka 2013. Pati.

Parhusip, H. A., S. Ayunani. 2009. Metode Finali Untuk Menentukan Berat Sapi Optimal. Prosiding Fakultas Sain dan Matematika UKSW: 12-13.

Prayitno, H. T. 2014. Strategi Pemanfaatan Kotoran Sapi. Jurnal Litbang Kabupaten Pati, 10(1): 4351.

Prayitno, H. T. 2015. Upaya Pemanfaatan Kotoran Sapi Sebagai Bahan Biogas, Pupuk Cair dan Pupuk Padat. Bunga Rampai: Dinamika Pembangunan Kabupaten Pati: 29-49.

Purnomosidhi, P., Suparman., J. M. Roshetko., Mulawarman. 2002. Perbanyakan dan Budidaya Tanaman Buah-Buahan dengan Penekanan pada Durian, Mangga, Jeruk, Melinjo, dan Sawo: Pedoman Lapangan. International Centre for Research in Agroforestry (ICRAF) dan Winrock International. Bogor, Indonesia: hal 41.

Salim, A. 2007. Penelitian Deskriptif Interpretatif. Direktorat Profesi Pendidik Direktorat Jenderal Peningkatan Mutu Pendidik dan Tenaga Kependidikan Departemen Pendidikan Nasional. https://www.google.co.id/webhp?s ourceid=chrome-

instant \&ion $=1$ \&espv $=2 \& i e=U T F-$ $8 \# q=$ metode + penelitian + deskripti f+salim, diakses tanggal 2 September 2015.

SNI 19-7030-2004 mengenai Kompos Dari Sampah Organik Domestik. 
Soekidjo. 1994. Pengembangan Potensi Wilayah. Bandung: Gramedia.

Suharijanto, 2011. Induksi Tunas Jeruk Pamelo (Citrus maxima Merr) Kultivar Bageng Secara Invitro dengan Pemberian Jenis dan Konsentrasi Sitokinin. Tesis. Pascasarjana Program Studi Agronomi. Surakarta: Universitas Sebelas Maret.

Fiana, Y., D. N. Purwantiningdyah., M. Rizal. 2015. Kajian Teknologi Pemupukan Terhadap Pertumbuhan Vegetatif Tanaman Jeruk Keprok Borneo Prima di Kabupaten Bulungan, Kalimantan Utara. Prosiding Seminar Nasional Masyarakat Biodiv Indon. 1(2): 319-323.
Wahyudi, J., A. D. Astuti. 2011. Pembuatan Pupuk Organik Cair Dari Limbah Biogas. Jurnal Litbang Kabupaten Pati, 7(1), 1216.

\section{BIODATA PENULIS}

Hermain Teguh Prayitno, lahir 11 April 1970 di kota Rembang Jawa Tengah. Magister Ilmu Lingkungan dari Universitas Diponegoro (UNDIP) Semarang tahun 2008. Saat ini bekerja sebagai peneliti pertama di Kantor Penelitian dan Pengembangan Kabupaten Pati. 